\title{
Inkluzív kormányzás az ipar 4.0 korában - Japán példája
}

Tanulmányunk azt a kérdést vizsgálja, hogy vajon össze lehet-e egyeztetni két, egymással látszólag teljesen szemben álló gazdaságpolitikai célt: a digitális transzformáció és ipar 4.0 előrelendítésének, illetve az inkluzív fejlődés biztosításának céljait. Kiindulásképpen rámutatunk arra, hogy napjainkban az inkluzív gazdasági kormányzás iránti igény sokkalta nagyobb, mint azt a szakma valaha is gondolta volna. Ennek belátásához a tanulmány először felfejti a manapság elharapódzni látszódó populizmus és az európai inkluzív növekedés közötti komplex kölcsönhatást. Ezután a sok tekintetben Európa jövőjét megtestesítő Japán digitális átalakulására és ipar 4.0 fejlesztésére koncentrálva szemléltetjük, hogy a Japán által kitüzött 5.0-ás társadalom célja voltaképpen a gazdaságpolitika értékalapúságának megtestesülése, amikor is a digitalizációt és az ipar 4.0 fejlesztéseket az inkluzív fejlődés szolgálatába állítják.*

Journal of Economic Literature (JEL) kód: O1, O25, O38, P47.

\section{Bevezetés}

Jelen írás azt a kérdést vizsgálja, hogy a digitalizáció és az új ipari forradalom gazdaságilag és társadalmilag sokat ígérő jelensége vajon miért intheti mégis különös óvatosságra a gazdasági kormányzást. Rámutatunk arra, hogy az inkluzív gazdaságirányítás iránti igény talán nagyobb, mint azt a szakma valaha is gondolta volna. Inkluzív növekedésen olyan gazdasági növekedést értünk, amely a lehetőségekhez mérten igazságosan oszlik meg a társadalomban, s eredeti célja szerint minden egyén számára igyekszik megadni annak lehetőségét, hogy személyes képességei értékteremtő és értelmes módon a saját és a köz javára kibontakozhassanak. Ennek belátásához számba kell vegyük a populizmus mozgatórugóit, ki kell térnünk a populizmus

* A Nemzeti Közszolgálati Egyetem Gazdaság és Versenyképesség Kutatóintézete támogatta.

Kovács Olivér a Nemzeti Közszolgálati Egyetem tudományos fömunkatársa (e-mail: Kovacs.Oliver. Istvan@uni-nke.hu).

A kézirat első változata 2021. július 25-én érkezett szerkesztőségünkbe.

DOI: https://doi.org/10.18414/KSZ.2022.2.255 
és az inkluzív növekedés kapcsolatára. Így tehetjük világossá, hogy mára az inkluzív növekedés és fejlődés egyre erősödő ellenszélnek van kitéve. Japán digitális átalakulására és ipar 4.0 fejlesztésére koncentrálva bemutatjuk, hogy a szigetország által elképzelt 5.0-ás társadalom voltaképp a gazdaságpolitika értékalapúságának megtestesülése, amikor is az inkluzív fejlődés marad a prioritás. Írásunkban amellett érvelünk, hogy az ipar 4.0 és a digitális transzformáció még jobban megköveteli az inkluziv kormányzást, ha és amennyiben a politikai stabilitást, a technológiai fejlödés társadalmi elfogadhatóságát és gazdasági kibontakozásának megvalósíthatóságát egyszerre igyekszünk szem előtt tartani.

\section{Populizmus, avagy út a szolgaságba?}

Kiindulópontként annak belátására van szükségünk, hogy az évtizedeken át elöszeretettel preferált konvencionális közgazdaság-tudományi elméletek hibásnak bizonyultak: nem a vágyott kiegyensúlyozott és fenntartható növekedés és fejlődés felé navigálták a világgazdaságot, hanem a kritikus instabilitásban játszottak tevőleges szerepet. A legjelentősebb ilyen ábrándok közé sorolható a szélesen értelmezett liberalizáció témaköreiben: 1 . az adócsökkentés (az adórendszerek progresszivitásának tudatos mérséklése a beruházási kedv feltámasztása, azaz a gazdasági dinamizálás érdekében), ${ }^{1}$ 2. a pénzügyi szféra deregulációja, illetve 3. a kereskedelmi korlátok lebontása. Az uralkodó közgazdasági narratíva szerint ezek mind garantálni hivatottak a magasabb profit elérhetőségét, ezáltal pedig a béralapú versenyképesség fenntartását. Mindezek mellett ma már számos - akkortájt igaznak hitt - közgazdasági összefüggést nem sikerül kimutatni és igazolni (a foglalkoztatás bővülése növeli az állami bevételeket, a termelékenység növekedését bérnövekedés kíséri, stb.). Ezek pedig olyan folyamatok, amelyek a társadalmi bizalmi infrastruktúrára bizonyosan negatív hatással vannak. A rendszerszintü kockázatok számbeli és szintbeli emelkedése, valamint az egyenlőtlen fejlődés ${ }^{2}$ az antiglobalista mozgalmak által fütött bizalmatlanságot táplált a kormányzatokkal szemben, és erőre kapott - sokszor csak átmenetileg - a populista ideológia, miközben megnőtt az autoriter értékek terjedési sebessége (Guiso és szerzőtársai [2018]).

A populizmus, a leegyszerüsített nézetek iránti kereslet valahol az emberi viselkedés autochton része. A világ komplexitásának megértéséhez mindig redukcionizmuson keresztül igyekszünk eljutni. Természetünknél fogva ódzkodunk

\footnotetext{
${ }^{1}$ Az OECD-országokban a legmagasabb jövedelműek átlagosan 66 százalékos adórátával kalkulálhattak 1981-ben, míg 1990-ben már csak 51 százalékkal, 2000-ben 47 százalékkal, 2008-ban pedig 41 százalékkal (https://www.oecd.org/social/OECD2014-FocusOnTopIncomes.pdf).

${ }^{2}$ A vagyoni egyenlőtlenségek tízszer nagyobbak, mint a flow kategóriájú egyenlőtlenségek (Piketty [2015], Atkinson [2017]). Az OECD-országokban átlagosan 4,5 generációba telik egy szegény családba született gyermeknek feljutni a középosztályba (ez a szám Magyarország esetében 7, de még a megfelelő német és francia adat is 6), a hetvenes évek közepe óta a medián háztartási nettó jövedelem növekedési rátája gyakorlatilag elenyésző. Komlos [2016] rámutat, hogy a középosztály zsugorodik, sőt el is tünik, jövedelme pedig 1979-2011 között szinte nulla ütemben nőtt (csak 0,1 és 0,7 százalék évente), míg a felső 1 százalék éves jövedelemnövekedése 3,4-3,9 százalék volt a vizsgált 32 év alatt.
} 
a bizonytalanság tól, ezért mindig bizonyosságra törekszünk. Azokat a dolgokat hiszszük igaznak, amelyekről már van valamilyen ismeretünk. Utóbbiból is következik, hogy a mai komplex kihívások rendszerével küzdő demokratikus gazdasági kormányzás rendkívül nehéz helyzetben találja magát, mert a többszörös áttéteken és nemlineáris visszacsatolásokon keresztül ható kölcsönhatások közepette nagyon nehéz kellően egyszerűen, ám hallatlanul precízen felvetni a megoldandó problémákat a választók számára, sőt egyre inkább az igaz, hogy ez egyszersmind lehetetlen. Mindez utat nyithat a „tényeken túli” (post-factual) világnak, a komplex problémákra egyszerủ válaszokat adó, karizmatikus vezetővel rendelkező autoriter rezsimeknek, valamifajta szimulákrumnak. ${ }^{3}$

Nemcsak arról van szó, hogy a populizmus valós társadalmi problémákat nem képes fenntarthatóan megoldani, hanem arról is, hogy a populizmus társadalmigazdasági instabilitáshoz, szociális krízishez, a demokratikus jogok drámai korlátozásához vezet. Paradox módon az eszkalálódó populizmus a gazdasági bizonytalanság inflálódásával jár (például az emberek életkilátásainak minél előbbi emelését ígérő populista és demagóg pártok hatalomra jutva az eladósodás útjára térítik a társadalmat, majd egy válság esetén a még populistább és még szélsőségesebb erők törhetnek előre, hiszen a társadalom nehezebben mond le már megszerzett jogairól, mintsem küzdene a jövőben esetleg elérhetőért). Amartya Sen vagy Deirdre McCloskey felfogásában ez az emberi képességek kibontakozási lehetőségeinek - aminek bővülése lenne az igazi fejlődés - csorbulását jelenti. ${ }^{4}$ Ekkor pedig korlátozottabbá válik a gazdasági-társadalmi spontaneitás is, aminek a fejlödés alapmotívumának kellene lennie. ${ }^{5}$

A populizmus erősödésével párhuzamosan mintha megkopott volna az inkluzivitás szándékának elve a modern gazdasági kormányzásban. Ezáltal a társadalmi mobilitás elakad: ha valaki szegény családba születik, akkor jellemzően alacsonyabb minőségü oktatásra, kedvezőtlenebb munkalehetőségekre, az eladósodás nagyobb kockázatára számíthat, életkilátásai rosszabbak lesznek. Mindez konzerválja az

\footnotetext{
${ }^{3}$ Ez a tényszerűség helyébe lépő látszólagosság, a csalókaság diadala (Baudrillard [1983]). Jó néhány ilyen eset említhető az amerikai elnökválasztás során. A Facebookon számos hamis hír terjengett; de idesorolhatók az áltudományos kutatási eredmények hatásai is (például egy tudományos alátámasztást teljesen nélkülöző, légből kapott „kutatási eredmény” hatására egyre kevesebben oltatták be magukat Japánban HPV ellen).

${ }^{4}$ A fejlődés képességalapú megközelítése (capability approach) régóta jelen van a szakirodalomban (lásd Sen-Sengupta [1983] vagy Sen [1993]), amely az emberek életének olyan oldalaival foglalkozik, mint az egészség, az oktatás, a közösségi hálózatok által nyújtott támogatások és természetesen a döntési szabadságuk is (dolgozhatnak, családot alapíthatnak, utazhatnak, vagy politikailag aktívak lehetnek). A téma régóta virágzik, lásd például a Journal of Human Development and Capabilities folyóiratot, amelyet a Human Development \& Capability Association gondoz, s amelynek első elnöke az a Nobel-díjas Amartya Sen volt, aki oroszlánrészt vállalt az ENSZ emberi fejlettségi indexének (Human Development Index, HDI) kidolgozásában. Ha a társadalom legnagyobb része jobban kibontakoztathatja képességeit (Sen [2021]), azaz az egyének több szabadságot élvezhetnek személyes céljaik megvalósíthatóságában, akkor a spontán ötletek, a technológiai és nem technológiai innovációk is könnyebben megvalósulhatnak.

${ }^{5}$ Flew [2006] Kína kapcsán érzékletesen világítja meg, hogy az új középosztály voltaképpen egybeesik azzal a kreatív osztállyal, amely az innovációs motor nélkülözhetetlen eleme.
} 
egyenlőtlenséget, és aláássa az államba és intézményeibe vetett társadalmi bizalmat. Az elszegényedés folyamata a fejlett világ sajátjává vált. ${ }^{6} 1980$ és 2015 között a közepes jövedelmü háztartásokban élők aránya az összlakosságon belül 64 százalékról 61 százalékra mérséklődött az OECD-országok átlagában. Való igaz ugyan, hogy ez évről évre bekövetkezö kis léptékü változás formájában öltött testet, mindazonáltal voltak (és jelenleg is vannak) országok, ahol mindez nagyobb sebességgel zajlott (és zajlik ma is) le (például Izraelben, Németországban, Finnországban vagy az Egyesült Államokban a csökkenés meghaladta a 4,5 százalékpontot is), ami megkérdőjelezhetővé teszi a gazdaságpolitikák szociális vetületének hatékonyságát, hovatovább belülről kódolja az elégedetlenséget, az állam cselekvőképességével kapcsolatos komolyabb aggályokat.

Mi több, a középosztály zsugorodása - még azzal együtt is, hogy a középosztálybeli dolgozók egyre változatosabb hajlandósággal fogadják el a közepes jövedelmü állásokat, sokuk ugyan magasabb jövedelmủ munkalehetöséget szerez meg, többségük jellemzően inkább lecsúszik az alacsonyabb jövedelmezőséget biztosító munkalehetőségek felé ${ }^{7}$ - egyúttal azt is jelenti, hogy ez a társadalmi réteg politikailag is veszít fontosságából (empirikusan igazolt, hogy a politikai rendszerbe, a kormányzásba nagyobb eséllyel és többen kerülnek be a középosztályból, ilyesformán megtámogatva a politikai stabilitást). E csoport elvékonyodása a fejlődés szempontjából nyugtalanító, ${ }^{8}$ mert éppen ez az osztály az, amelynek képviselőiben megvan a felfelé törekvés vágyának az a kritikus szintje, amely rendszerszinten nélkülözhetetlen (ez a szellemi és más eröforrások, illetve megtakarítások jóvoltából megvalósítható kutatás-fejlesztési és innovációs beruházások terén, az önfejlesztés/önképzés terén nyilvánul meg leginkább), ${ }^{9}$ illetve az a vágy, amely rendszerszintü fontossága mellett arra irányul, hogy nem szeretnének leszakadni, ezért pedig a demokratikus berendezkedés mentsvárai abban az értelemben, hogy a fékek és ellensúlyok rendszerének egészséges fenntartását mindig támogatják (ne legyenek oligarchák, ne legyen túl nagy az egyenlőtlenség, visszafogottabb legyen a korrupció, stb.). ${ }^{10} \mathrm{~A}$ középosztály túlnyomóan a politikai stabilitás és

${ }^{6}$ Az Eurostat [2022a] adatai alapján látható, hogy az EU27-ben tartósan nő a jövedelemegyenlőtlenség. Az uniós lakosság legjobban kereső ötöde 2010-ben 4,9-szer többet keresett, mint a jövedelmi skála alsó ötödébe tartozók. 2018-ra ez az érték megközelítette az 5,2-et. A szegénység vagy társadalmi kirekesztés kockázatával szembesülők száma sem mutat látványos javulást (2010-ben 117 millió, 2018ban még mindig 110 millió).

${ }^{7}$ Az OECD egy tanulmánya bemutatja, hogy a vizsgált országok többségében igenis csökkent annak a valószínüsége, hogy egy magasan képzett munkavállaló a magasabb jövedelmű osztályba tartozzon. Sőt a felső jövedelmű osztályban található magasan képzett munkavállalók aránya 25 százalékról 20 százalékra csökkent. Az alacsony és közepes képzettségű középosztálybeli munkavállalók inkább az alacsonyabb jövedelmű osztály felé mozdultak el (OECD [2019a] 43. o.).

${ }^{8}$ Vagyis az a tény, hogy az elmúlt 35-40 év során a bérkülönbségek csak fokozódtak, ezáltal a legalacsonyabb fizetésből élők és a középosztályban lévők közötti különbség erőteljesen csökkenni kezdett.

${ }^{9}$ A boldogság versus jövedelem paradoxonjáról híres William Easterly igazolta azt is, hogy a közepes jövedeleműek társadalmon belüli részesedésének mértéke egy sor nagyon fontos indikátorra hat, így a várható élettartamra, a csecsemőhalandóságra stb. (Easterly [2001]).

${ }^{10}$ Fontos, hogy a középosztály zsugorodása rendszerkockázatot jelent. Ez a réteg képviseli a társadalmi többséget, szavaz tömegével a választásokon (nem pedig a leggazdagabb 1 százalék vagy a legszegényebb 20 százalék), ezért ez képes a legjobban aláásni a politikai stabilitást. A lecsúszó 
a jó kormányzás híve (Birdsall [2016]), segít megakadályozni a túlzott mértékű politikai polarizációt, és elösegíti a kormányon belüli kompromisszumokat (Madland [2015]). Ha pedig mindezek ellenére a középosztály zsugorodik, akkor arra kell gyanakodnunk, hogy a társadalmi-gazdasági rendszer konfigurációja olyan fejlődési szakaszban van, ami ilyen formában sem mennyiségben, sem minőségben nem képes „jó munkahelyekkel” szolgálni (Rodrik [2019]). Mindez arra hívja fel a figyelmet, hogy a termelés struktúrája diszharmonikus viszonyban van a munkaerőbázis struktúrájával. Nem is lehet meglepő, hogy a termelékenységi növekedés nagyjában-egészében a hetvenes évek közepe óta romló dinamikát mutat. Másképpen fogalmazva, a termelés egyre nagyobb része készségintenzív, amivel nem tud a munkaerő lépést tartani (egyre nagyobb része alacsonyan képzett ahhoz). ${ }^{11}$ Mindebből persze nem az abszolút értelemben kevesebb állam narratívája következik, hanem éppen ellenkezőleg, egy a korlátait felismerö, szerényebb beavatkozásokat tervezö, önmagát a gazdasági-társadalmi innovációs ökoszisztéma szerves részeként definiáló államra van szükség, amely folyamatosan arra törekszik, hogy a komplex kihívások kezelése (nem a végső megoldani akarása!) tartós maradhasson, így erősítve a rendszer rezilienciáját.

\section{Erősödő ellenszél - az inkluzív fejlődés exkluzivitásáról}

Az inkluzivitás mára sokkalta gyengébb formában hatja át a társadalmi-gazdasági rendszert, amit jól jelez az a tény, hogy a fejlett világban jelentősen megcsappantak a - relatíve jól fizető, a szakmai és a magánélet egyensúlyát lehetővé tevő, a középosztály életszínvonalát biztosító - jó munkahelyek, amelyek a társadalmi mobilitás meglétét jeleznék. ${ }^{12}$

Az inkluzivitás a politikai stabilitás kulcsává vált, az inkluzív növekedés/fejlödés megkerülhetetlen elöfeltétele az állam fenntartható jóléti szolgáltatásainak, a jóllét kollektív elömozdithatóságának. Inkluzív fejlődés nélkül semelyik ország sem tud

tömegek gazdaságtörténileg dokumentált módon elrettentik a befektetéseket, lefojtják a gazdasági növekedést (Alesina-Perotti [1996]) - mi több, hibás az a narratíva, hogy erős középosztályt kell teremteni a gazdasági növekedés által, mert oda-vissza csatolnak a folyamatok, hovatovább a középosztály a forrása a gazdasági növekedésnek, tömegeinek kiábrándultsága megtépázza az állami intézményekbe vetett bizalmat, ami nélkül pedig sem tartós növekedés és fejlődés, sem hathatós gazdaságpolitika nem képzelhetö el.

${ }^{11}$ Ha a Világbank-, az OECD- és az Eurostat-statisztikákat tekintjük, akkor belátható, hogy a teljes tényezőtermelékenység átlagos növekedési rátája az 1970-es évektől napjainkig romlást mutatott a fejlett világban, így az Egyesült Âllamokban, Japánban, a teljes euróövezeteben, beleértve Németországot is (lásd Bergeaud és szerzőtársai [2016]), utóbbiról átfogó és komparatív látlelettel szolgál Fukuda [2020].

${ }^{12}$ Megjegyezzük, hogy a jó munkahelynek számtalan definíciója van használatban. A Nemzetközi Munkaügyi Szervezet (International Labour Organization, ILO) például a jó munkahely kapcsán tisztességes munkáról beszél, amely az emberi méltóság tiszteletét, az egyenlőséget, a méltányos jövedelmet, a biztonságos munkakörülményeket jelenti. A híres Rió + 20 konferencia - amely a fenntartható fejlődési célok jegyében és az azok elérhetőségét biztositó nemzetközi párbeszéd nyomatékosabb megindításáért zajlott le 2012-ben - dokumentuma is megjegyzi, hogy a tisztességes munka hiánya egyre égetőbb probléma a világgazdaság egészében (https://www.un.org/ga/search/view_doc. asp?symbol=A/69/700\&Lang=E). 
a prosperitás felé navigálni, avagy a fenntartható fejlődési célokért síkra szállni. Ha az egyenlőtlenségeket tovább erősítő folyamatok nincsenek korlátozva, akkor egyre csak szükül az a társadalmi réteg, amelyik produktív és jó munkahelyeken teremthet értéket, s egy apró kisebbség körében koncentrálódhatnak a nagy hasznok (a technológiai fejlődésből eredők is). Napjaink egyik égető kérdése, hogy vajon mi módon érjük el az inkluzivitás erősítését: azt, hogy a növekedés mindenki számára biztosítson hasznot; s mindenki - aki akar és tud - értelmes és értékes munkával hozzájárulhasson ehhez a folyamathoz.

Az inkluzív fejlődés exkluzivitása abban áll, hogy mára a társadalmi-gazdasági innovációs ökoszisztéma rengeteg inkluzivitással ellentétes folyamattal terhes, amelyek nehezítik az inkluzív növekedést és fejlődést támogatni igyekvő gazdasági kormányzást. A teljesség igénye nélkül a következőket említjük meg - reflektálva részben a korábbiakban előadottakra: 1 . az információs és kommunikációs technológiára építő, évtizedes múltra visszatekintő automatizálás és a globalizáció együttes hatása (például kezdetben az új technológia alapvetően a magasan képzettek hatékonyságát támogatta, majd kikezdte a közepes képzettséggel rendelkezők munkáját, és megindult a középosztály zsugorodása - OECD [2011]); 2. a reálgazdaságon túlterjeszkedő pénzügyi szektort nagyvállalati preferencia jellemzi, azok dominanciája pedig fokozza a vállalatok közötti egyenlötlenséget; 3 . az intézményi rendszer gyengülése nem ellensúlyozza a fenti folyamatokat (például a munkaerőpiaci szabályozás lazulása, a társadalombiztosítási védőháló rendszerének fejletlensége, a szakszervezetek szerepének megcsappanása stb.); 4 . az adórendszerek a nagyvállalati dominanciával együtt inkább a nagy költségmegtakarítást lehetővé tevő automatizálást ösztönzik (például egy gép beszerzése adó- és egyéb kedvezményekkel, a munkaerököltség megtakarításával jár, míg egy új foglalkoztatott csak többletkiadással jár); és 5. az államok mindezen fejlemények és a koronavírus-járvány kereszttüzében - a gazdaság leállását elkerülendő - inkább az automatizálási stb. folyamatokra erősíthetnek rá (különösen olyan országokban, ahol krónikussá vált a munkaerőhiány). ${ }^{13}$

Történik mindez egy olyan korban, amelyet a komplexitás tudománya - új, interdiszciplináris partnerségeket alkalmaz az olyan alterületek között, mint az ökológia, a közgazdaságtan, az információs tudomány, a fizika, a szociológia stb. - fázisátalakulásként tart számon, vagyis amikor egy minőségében és föleg struktúrájában merőben új technológiai-gazdasági paradigma kialakulásának lehetünk tanúi: a digitális transzformációnak és az ipar 4.0 kiteljesedésének. Ez a kor az automatizáció és robotizáció, valamint a mesterséges intelligencia ${ }^{14}$ rohamléptékủ elterjedésével munkahely-megtakarító jellegü, és más szektorok abszorpciós kapacitása ezúttal messze kisebb, mint a korábbi technológiai forradalmak idején. Például Kínában a munka-

${ }^{13}$ A koronavírus-járvány 2020. március-áprilisi időszakában hat hét leforgása alatt 35 százalékkal esett vissza az S\&P 500 és Dow Jones (ipari átlag) indexe, ehhez a 2008-as válság idején 6 hónapra volt szükség. Nehéz tagadni, ilyen időszakban sokkal vonzóbb az automatizálás és robotika (vagy a mesterséges intelligencia), amikor a világjárvány miatt eleve számos dolgozót elbocsátottak.

${ }^{14}$ A mesterséges intelligencia egy lehetséges definíciója a következőképpen hangozhat: Big Datára és gépi tanulásra építő, algoritmuscentrikus, komplex társadalmi-technológiai rendszerek, amelyek szuperszámítógépeken futva képesek tanulni, fejlődni és bizonyos mértékig előre látni. 
helyek 77 százaléka kiváltható lenne automatizálással, ez az arány az Egyesült Államokban 47 százalék, Európában pedig 54 százalék. Az általunk is említett zsugorodó és évtizedek óta inkább stagnáló vagyoni helyzetü és életszínvonalú középosztályban hat közepes jövedelmet biztosító munkahelyből egy szembesül az automatizálás magas kockázatával (OECD [2019b] 13. o.). ${ }^{15}$

Noha a mesterséges intelligencia kutatása és alkalmazhatóságának kérdése rendkívül régóta napirenden van, fejlesztése az elmúlt évtizedben felgyorsult, és jobbnál jobb eredmények is születnek. A mesterséges intelligenciával kapcsolatos szabadalmak világszerte évente átlagosan 6 százalékkal növekedtek 2010 és 2015 között (Japán, DélKorea és az Egyesült Államok tulajdonolják a globális mesterséges intelligenciával kapcsolatos szabadalmak kétharmadát - OECD [2017]). A mesterséges intelligencia széles körü társadalmi-gazdasági hatásai közül (Big Data-kezelhetőség, minták feltárása, precízebb előrejelzések, növekvő termelékenység, alacsonyabb költségek, magasabb biztonság, a komplex kihívások jobb megértése és kezelhetősége stb.) tanulmányunk szempontjából a munkahely-megtakarító karaktere a fontos. A mesterséges intelligencia minden bizonnyal újradefiniálja azt, amit ma munkának, illetve munkahelynek nevezünk. Minden vélelmezés szerint a munka világát rendkívül sokan kénytelenek lesznek elhagyni (Acemoglu-Restrepo [2019]). Ez számottevő társadalmi bizonytalanságot szül majd olyan területeken, mint a társadalmi-gazdasági rendszer fenntarthatósága, a társadalmi identitás vagy az adózás, a szakpolitika, a gazdasági növekedés és fejlődés. A digitális transzformáció trendjében fejlődő és kiteljesedő mesterséges intelligencia összhatásával kapcsolatosan kínos homály lepi el az empirikus kutatásokat, mindazonáltal leszögezhető, hogy nem feltétlenül csökkenti a fenntartható fejlődési célokért küzdő globális világgazdaság előtt álló kihívások komplex rendszerét. A teljesség igénye nélkül csak megemlítjük, hogy a mindent átható digitalizáció és az adatokra épülő mesterséges intelligencia olyan dimenziókban jelenthet fenyegetést, mint a megemelkedő energiatermelési igény, a kiberbiztonsági sérülékenység vagy a társadalmi különbségek továbbmélyítése (digitális szakadék a digitális gazdaság nyertesei és azok között, akik elvesztik miatta állásaikat, gazdasági erőforrásaikat s egyéb társadalmi kedvezményeiket - Prettner-Bloom [2020]). ${ }^{16}$

Összefoglalva, az inkluzív fejlődés biztosítása korunk társadalmi-gazdasági innovációs ökoszisztémáinak egyik legnagyobb kihívása. Elérését nehezíti az erős ellenszél. Történelmi tapasztalatunk az, hogy bizonyos esetekben a társadalmak felemelkednek a technikai fejlesztések révén, és összeomlanak, amikor már képtelenek kontrollálni a folyamatokat, ezért pedig nem tudják fenntartani és tovább fejleszteni a társadalmi kohéziót. Ebből fakadóan értékalapú közgazdaságtanra s arra építő értékalapú gazdaságpolitikai megközelítésre van szükség. A következőkben pontosan az értékalapú gazdasági kormányzást illusztráljuk Japán példáján, ahol

\footnotetext{
${ }^{15}$ A gépi tanuláson vagy mesterséges intelligencián alapuló megoldások miatt nemcsak a kétkezi, de a komolyabb szellemi erőfeszítéseket igénylö, szofisztikáltabb munkák is automatizálhatók és robotizálhatók (például a turizmusban, a vendéglátásban, a teherszállításban, de még az ügyvédek, a forgatókönyvírók stb. esetében is).

${ }^{16}$ Tegyük hozzá, hogy a gazdasági átalakulás folyamataihoz idő kell. Gondolhatunk itt William F. Ogburn híres kulturáliskésés-elméletére a technológia diffúzióját illetően (Ogburn [1964]).
} 
él még a mondás, miszerint „az emberi lét szélben libegő gyertyaláng”. Mint bemutatjuk, a japán gazdasági kormányzás őrzi az inkluzív fejlődés „lángját” a digitális átalakulás korában (is).

\section{Japán - útfüggőség, inkluzív fejlesztés és ipar 4.0}

A következőkben azt szemléltetjük, hogy Európa sokat tanulhat az inkluzivitás szellemiségével szinte strukturálisan áthatott Japán példájából. Elöször betekintést nyújtunk az inkluzív növekedés és fejlődés terén tetten érhetö legfontosabb folyamatokba Japán és az EU esetében. Ezután az irodalmak szokásos analitikus megközelítésén túlmutató s talán holisztikusabb narratívát vázolunk fel arról, hogy miképpen is vált az inkluzivitás a japán gazdaság példamutató tőkéjévé. Végezetül pedig bemutatjuk, hogy a digitális transzformáció, az ipar 4.0 időszakának hajnalán milyen, szintén az inkluzív fejlődést kultiváló stratégiával képzelik el a digitális forradalom emberléptékűvé tételét (5.0-ás társadalom).

\section{Inkluzivitás madártávlatból - EU és Japán rövid összevetése}

A következőkben nyilvánosan hozzáférhető, mértékadónak számító nemzetközi statisztikai adatbázisokra építve hangsúlyozzuk, hogy mind Japánban, mind az Európai Unióban egyre inkább szükség van az inkluzivitás erősítésére.

A munkaképes korú lakosság (15-64 év) százalékos részaránya a populáción belül 2004 óta csökkenő trendet követ, és a csökkenés üteme egyre csak gyorsul Európában (ezt lényegében a koronavírus-járvány ciklikusan visszatérő hullámai, valamint a digitalizáció okozta munkaerő-megtakarító technológiai átállás strukturális hatásai miatt lehet megfigyelni). ${ }^{17}$ Ezzel pedig az EU elérni látszik azt a szintet, amit Japán kezdett produkálni a kilencvenes évek közepétől kezdve (Kirkegaard [2019] 5. ábra). A munkaerő csökkenése - mint demográfiai jelenség - kártékonyan érinti a vállalkozói környezetet, a startupok aktivitását, miután az állam túlterhelése (fogyatkozó adóbevételek a terebélyesedő jóléti kiadások finanszírozására), az alacsony termelékenységi dinamika, az eladósodás ördögi köre válik meghatározóvá (a háztartások, a vállalatok eladósodása, illetve az államadósság magasabb szintek felé történő tartós elmozdulása).

Az inkluzív növekedés és fejlödés alakulását statisztikai közelítő változók segítségével ragadhatjuk meg - ami részben hasonlít az OECD-nél alkalmazott megközelítésre, annak némiképp egyszerüsített változata ${ }^{18}-$, amelyek Japán esetét alapul véve Európa demográfiai jövőjéről tájékoztatnak. A következő dimenziók alá szer-

${ }^{17}$ Az Eurostat [2022b] szerint a koronavírus-járvány tartós trendekben okozott töréseket. Például újra elkezdett gyarapodni a munkaerő-állományon kívüli népesség részaránya, amely közel 17 éven keresztül mutatott mérséklődést. A 26,6 százalékos szintről 2019-re 27,1 százalékra emelkedett.

${ }^{18} \mathrm{https} / /$ www.oecd-forum.org/posts/52681-inclusive-economic-growth-are-we-talking-aboutthe-same-thing. 
vezzük közelítő indikátorainkat: 1 . a növekedés előnyeinek egyenlő megosztása, 2. inkluzív és jól müködő piacok, valamint 3. egyenlő lehetőségek/a jövő prosperitásának alapjai.

1. A növekedés elönyeinek egyenlö megosztása dimenziót két indikátorral közelítjük: $a)$ a háztartások rendelkezésre álló jövedelmének alakulása; $b$ ) a lakosságarányos szegénység.

a) A háztartások rendelkezésre álló jövedelmének százalékos változása: mind Japánban, mind pedig az Európai Unióban megfigyelhető a stagnálás visszavisszatérő mintázata (hiszen 2000-ben még 3,1 százalékos növekedést lehetett látni az EU-ban, ami a 2008-as pénzügyi és reálgazdasági válság beköszönte elött viszont már csak 1,2 százalék volt - nem beszélve az utána következő időszakról, például 2020-ban -0,2 százalékos visszaesést könyvelhettek el a háztartások). Németország Japánhoz hasonlóan 0,3-0,4 százalékos növekedést mutatott e tekintetben 2000-ben, a válságot megelöző évben (2007) a japán adat 1,2 százalék, a német 0,2 százalék volt; a koronavírus-járvány előtti utolsó esztendőre pedig mindkét országban megint csak jelentős visszaesést láthatunk (Németországban a 2016. évi 3,1 százalék 2017-re 1,6 százalékra csökkent; Japánban pedig 1,4 százalékról 0,6 százalékra esett vissza).

b) A lakosságarányos szegénység (például a vásárlóerő-paritáson napi 3,2 dollárból élők százalékos aránya): igaz ugyan, hogy a szegénység és a szociális kirekesztés által veszélyeztetett lakosság csökken az EU-ban (a 2011. évi adat még 11,8 millió főt számlált, míg a 2019-es már csak 9 milliót), ${ }^{19}$ ha azonban a Világbank számításaira hagyatkozva megnézzük, hogy miképp alakult a háztartásokban élö azon emberek részaránya, akiknek az egy före jutó fogyasztása és jövedelme nem éri el a napi 3,2 dolláros szegénységi küszöböt, akkor például azt látjuk, hogy az EU növekedését jelentősen meghatározó Németországban ez az érték is inkább romlott, mintsem javult volna (2000-ben 0,23 százalék volt, míg 2019-re 0,24 százalék), Japánban pedig kifejezetten magasan konzerválódott, ahol is 0,98 százalékról 0,94 százalékra mérséklődött. ${ }^{20}$

2. Az inkluzív és jól müködő piacok dimenzióját három indikátorral közelítjük: a) a termelékenység dinamikájával, $b$ ) a foglalkoztatottság szintjével és $c$ ) a kis- és középvállalatok hitellel való ellátottságával.

a) A munkaerö-termelékenység éves változása (százalék) az OECD-adatok szerint romló tendenciát követ mind az EU28 átlagában, mind az uniós magország (Németország), illetve Japán esetében. A 2000. évi növekedési ráták (Németország 2,48 százalék, EU28 3,2 százalék, Japán 2,89 százalék) szemlátomást mérséklődtek a 2008-as válság előtti utolsó esztendőre (Németország 1,18 százalék, EU28 0,96 százalék, valamint Japán 0,63 százalék); a koronavírus-járvány előtti 2018-as évre pedig az indikátorok a stagnálás tendenciáját jelezték (Németország 0,4 százalék, EU28

\footnotetext{
${ }^{19}$ Eurostat [ILC_PEES0] (https://appsso.eurostat.ec.europa.eu/nui/show.do?dataset=ilc_pees01\& lang=en).

${ }^{20}$ Japánban már a napi 1,9 dolláros szintű szegénységi küszöb alatt élők aránya is növekedésnek indult (2000-ben arányuk még csak 0,48 százalék volt, 2019-ben már 0,73 százalék), ami egyébként nem illeszthető bele a világtendenciába. Az adatokat lásd: Világbank, PovcalNet adatbázis: http://iresearch. worldbank.org/PovcalNet/povDuplicateWB.aspx.
} 
0,7 százalék, valamint Japán 1,1 százalék). ${ }^{21}$ Ezért lehet, hogy az általános innovációs teljesítményt (a termelékenységi növekedés azon része, amelyet nem a munkaerő és nem a tőke eredményez, hanem technológiai és nem technológiai innovációk) megragadni igyekvő többtényezős termelékenység mind a német, mind a japán gazdaság esetében gyengülésröl árulkodik: 2000-ben még ezek az értékek Németországban és Japánban rendre 1,6 százalék és 1,7 százalék, 2007-re már 1,0 százalék és 0,5 százalék, míg 2018-ra -0,1 százalék és 0,2 százalék. ${ }^{22}$

b) Miközben az aggregált foglalkoztatottsági ráta látszólag javulásról árulkodik - 2000-röl 2019-re az EU27-ben 61 százalékról 68,5 százalékra; Németországban 65,4 százalékról 76,4 százalékra, Japánban pedig 68,9 százalékról 77,7 százalékra -, addig mélyebb bontásban kitetszik a gazdaságok inkluzivitással ellentétes karaktere, vagyis elsősorban az 55-64 éves korosztályban nőtt a foglalkoztatottság, míg a 25-54 év közöttiek részaránya a foglalkoztatottakon belül összességében és tartósan zsugorodó pályán van (2005-ben még 79,1 százalékos volt a részarányuk, 2020ra már csak 73,8 százalék). ${ }^{23}$

c) A kis- és középvállalatok számára nyújtott hitelállomány aránya nemzetközi összevetésben a teljes hitelállományon belül alapvetően stagnál, nagyon lassú mérséklődést mutat (2007-ben 69,6 százalék, 2018-ban 65,9 százalék), következménye ez annak, hogy 2007-2012 között jelentősen csökkent a kis- és középvállalatok számára nyújtott hitelek és kölcsönök mennyisége, ami arra utal, hogy ez a szektor nem jut könnyen pótlólagos pénzügyi forráshoz. Ezért nem meglepő, hogy a vállalati csődök gyakorlatilag 100 százaléka a kis- és középvállalati szektorban történik (ezek aránya 2007 óta csökkenő tendenciát mutat, amikor még 14 ezer kis- és középvállalat ment csődbe, 2018-2019-re már csak 8400 cég - OECD [2020]).

3. Az egyenlő lehetőségek/a jövő prosperitásának alapjai dimenziót két indikátorral közelítjük: $a$ ) nemek közötti bérszakadék és $b$ ) inkluzivitás a fiatalság esetén.

a) Nemek közötti bérszakadék: Japánban ez hagyományosan kimagasló mértékü - aminek elsődleges megjelenési szintje a nagyvállalatokon belül tapasztalható kollegiális bérdifferencia, hiszen a nagyok jobban képesek bevonzani és megőrizni a magasabban képzetteket, valamint kapacitásaik fényében differenciáltabb és nagylelkübb kompenzációs rezsimeket tudnak müködtetni ${ }^{24}$-, ugyanakkor az elmúlt 30 évben fokozatosan csökkentette a rést az EU magországának számító Németországgal, hiszen míg 2000-ben a japán érték 33,9 százalék volt, a német

${ }^{21}$ OECD Labour productivity and utilisation, OECD iLibrary: https://www.oecd-ilibrary.org/ economics/productivity/indicator-group/english_0bb009ec-en.

${ }^{22}$ OECD Multifactor productivity: https://www.oecd-ilibrary.org/economics/multifactor-productivity/ indicator/english_a40c5025-en.

${ }^{23}$ Employment and activity by sex and age [lfsi_emp_a]: https://appsso.eurostat.ec.europa.eu/nui/ show.do?dataset=lfsi_emp_a\&lang=en.

${ }^{24}$ Természetesen ez sem igaz mindig, hiszen a japán társadalom kulturális háttere a közösségi, a csoporttudat primátusát eredményezi, azaz a kollektív teljesítmény preferálását (Sakamoto és szerzötársai [2012]), mivel a nagy bérdifferenciák kialakulásának a kulturális értékrend komoly ellenösztönzője (Ikeuchi és szerzőtársai [2021]). 
pedig 19,6 százalék, addig 2017-re előbbinél 24,5 százalékot, a német gazdaságnál pedig 16,2 százalékot regisztrálhattunk.

b) A fiatalok azon aránya a teljes fiatalságon belül, akiket nem foglalkoztatnak, és oktatási/képzési tevékenységben sem vesznek részt: e tekintetben Japán és Németország hasonló pályán mozog, az OECD utolsó elérhető adatai alapján előbbi esetében ez az arány 8,6 százalék volt (2014), míg a megfelelő német adat 9,8 százalék (2016) (OECD [2022]).

Mindezekből kitetszik, hogy Japánban az inkluzivitás meglehetősen törékeny természetü, veszélyeztetettségi foka pedig igen magas a digitális forradalom és az ipar 4.0 inkluzivitást kikezdő természetének fényében.

\section{A japán inkluzivitás a máig ható múlt árnyékában}

A digitális transzformáció, az ipar 4.0, az automatizálás és robotizálás, valamint a mesterséges intelligencia területén való japán fejlődési út számos megközelítésben vizsgálható. Jelen írás egy árnyaltabb megközelítést javasol: vegyük figyelembe a japán társadalmi-gazdasági innovációs ökoszisztéma eddigi útját és teljesítményét, illetve szürjünk le tanulságokat a gazdasági kormányzási gyakorlatból, ami a digitális transzformáció kiteljesedésének potenciáljáról tájékoztathat bennünket. Központi gondolatunk az, hogy Japánt útfüggő szolidaritás jellemzi, ami komoly tehetetlenségi erőt képvisel, így mesterségesen visszafogott és mérsékeltebb digitális transzformációra (munkahely-megtakarító automatizálásra, robotikára, mesterségesintelligencia-fejlesztésekre, ipar 4.0 technológiákra) van inkább kilátás. Az útfüggő szolidaritás belátásához egy olyan utat választunk, hogy áttekintünk további két, egymáshoz kapcsolódó japán jellegzetességet: 1. paradox kettősség, 2. gyengélkedő innovációs dinamizmus.

Paradox kettősség jellemzi Japánt. Egyfelől bizonyos értelemben nyitott - azaz a társadalmi-gazdasági fejlődést a globális versenyelőnyök pásztázásával képzelte el, és így érte el a ,japán növekedési csodát” a nyolcvanas évek közepéig. Másfelől viszont kulturálisan lassabban vált: a szigetországi mivoltból, a földrengéseknek való kitettségből fakadóan a kiszolgáltatottság érzése erős. A japánok többsége nagyon tart attól, hogy a következő generációnak már nem lesz ilyen életszínvonala (ezért is lehet oly alacsony a születésszám). ${ }^{25}$ Ebből fakad egy, a japán társadalmi-gazdasági rendszerre oly jellemző attribútum, a szolidaritás átlagosnál jóval erösebb volta.

\footnotetext{
${ }^{25}$ Ezt tükrözi az a tendencia, hogy Japán a világ legeladósodottabb állama (a GDP 250 százaléka fölötti adósságrátával), amivel a világ legalacsonyabb szintű inflációja párosul, továbbá az a tény, hogy a megtakarítási hajlandóság globális összevetésben is egyedülállóan magas. Továbbá, a World Values Survey 2021-es kiadásában (https://www.worldvaluessurvey.org/WVSNewsShow.jsp?ID=439) Japán kapcsán egyértelműen látható, hogy a japánok többsége nem érzi azt, hogy megfelelően tudná kontrollálni életét, ebből fakadóan szeretné, ha a következő generáció már nem a kemény munkát (ami a jelenlegi életszínvonal továbbvitelének biztonságérzetét nyúitja), hanem a képzelőerőt értékelné, hiszen teljesen más, a jelenlegivel összeegyeztethetetlen életvitelre kell berendezkedniük egy sor folyamat miatt (például klímaváltozás stb.).
} 
Gyengélkedő innovációs alapjárat is jellemzi Japánt. Az innovációs motor teljesítményét nagyban befolyásolta, hogy a különböző folyamatok konfigurációja abba az irányba mutat(ott), hogy a nagyvállalatok és nagy konglomerátumok végső soron visszatartsák a fejlődést, azaz az innovációs tevékenység intenzitását: inkább kisebb léptékü, kisebb hozzáadott értéket képviselö termékeket, s azokat is elnyújtva dobnak piacra. Ebben a folyamatban a következő tényezők szerepét nem lehet elvitatni: 1 . az 1985-ös Plaza-egyezmény buborékképző ereje, 2. a telekárak szárnyalásának negatív következményei, 3. a „kicsi szép” eszméjének megbomlása, a monopolista innovációs hajlam erősödése és 4 . a stagnálás.

A második világháború utáni japán csoda nagyjában-egészében 1985-ig tartott, konkrétan a Plaza-megállapodásig, aminek többek közt az lett az eredménye, hogy a folyófizetésimérleg-többlettel rendelkező Németország és Japán a belső kereslet élénkítésébe kezdett, és felértékelte - illetve hagyta felértékelődni - nemzeti valutáját is. A gazdaságélénkítésbe a költségvetési politika is beszállt, 1989-től költségvetési élénkítő csomagot fogadtak el, ám a pótlólagos források inkább a relatíve gyorsabb megtérülést lehetővé tevő ingatlanpiac felé kezdtek áramlani, ezért nem folytatódott a szerves és fenntartható tartós befektetési gyakorlat. A helyszükével küszködő gazdaságban a miópia komoly buborékosodáshoz vezetett.

A felértékelődés miatt megreccsent a japán gazdaság exportorientációs jellege, ami erősen hozzájárult a buborékosodáshoz: a telekárak gyors emelkedése ${ }^{26}$ lefojtja a gazdasági dinamikát, kiváltképp azért, mert megnehezíti a startupok piacra lépését és fejlődését. ${ }^{27}$ A növekvő telekárak sok egyéb költséget is megemeltek, s talán ez az egyik fö oka annak, hogy nagyon lecsökkent a gyermekek száma, ami meggyorsította a japán társadalom elöregedését. A dolgozók reálbére régóta stagnál. ${ }^{28}$ Iggy a belső kereslet/ fogyasztás nem tud fenntarthatóan növekedni. Ez melegágya a deflációnak és a kockázatkerülő beruházási mentalitásnak, amin ma sem sikerült még teljesen túljutni. Utólag azonosítható még egy durva hiba, amit a japán pénzügyi vezetés követett el néhány évvel a Plaza-egyezmény után: felemelték a tőkemegfelelési mutatót 4 százalékról 8 százalékra (Kang [2017]), ami drasztikusan lefojtotta a gazdasági dinamizmust (mivel az alaptőkét nem könnyü emelni, így a bankok visszafogták a kölcsönnyújtási/hitelezési volument). Ez is az új belépők ellen hatott. Vagyis a telekárak növekedése, plusz az említett fejlemények eredményeképp a nagyvállalatok dominálhattak, míg a kicsik helyzete sokkal rosszabbá vált.

Japán a nagyvállalatok, a hatalmas konglomerátumok országa lett, és sokáig úgy festett, hogy a robotika - ami nagy beruházási igényü, és csak a nagyon nagyok rendelkeznek hozzá megfelelő anyagi, menedzsmenti és szervezeti erőforrásokkal - ipari

\footnotetext{
${ }^{26}$ A japán telekárak összege duplája volt az Egyesült Államokénak.

${ }^{27}$ Hawkins [1993] többek közt a telekárak emelkedésével magyarázta az induló és főleg független vállalkozások számának tartós esését. A kilencvenes évek közepe óta sem történt látványos javulás nemzetközi összevetésben a startupok terén (Kettenhofen [2021]).

${ }^{28} 1995$ és 2013 között a reálbérek mediánja csupán 0,2 százalékkal emelkedett (OECD [2018b] 56. o.). Chun és szerzötársai [2021] arra jut, hogy 2000 és 2020 között a munkatermelékenység nagyjában-egészében 22,8 százalékkal javult Japánban, míg a reálbérek mindössze 2,6 százalékkal emelkedtek ez idő alatt.
} 
felhasználása elképesztő növekedési rátákat fog eredményezni. ${ }^{29} \mathrm{Nem}$ így lett (Robots... [1982]). Beindult Swan [1970] kifejezésével élve az a monopolista innováció, amikor a nagyok lassan innoválnak, elsősorban kisebb újításokat hajtanak csak végre, mert így lehet tartósan magasabb profitokat realizálni. Emiatt viszont nemzetközi összevetésben is alacsony lett a japán vállalkozási hajlandóság és képesség új vállalkozások indítására, az innovatív ötletek piaci megvalósítására. ${ }^{30}$ Vagyis Japánban a termelékenység növekedése ellen ható erőteljes komplex mechanizmus alapozza meg a stagnálást (a Világbank adatai ${ }^{31}$ szerint 2019-ben 0,7 százalékos reálGDP-növekedést regisztráltak, 2020-ban pedig a koronavírus-járvány hatására már $-4,8$ százalékos zsugorodást). Ilyen körülmények között a szolidaritás eszméjének átlagon felüli erőssége nem meglepő. Nem véletlen, hogy a buborék kipukkanásakor a gazdasági kormányzás nem tekintette prioritásnak a rossz hitelek kiszelektálását, $s$ ezáltal lélegeztetőgépen tartottak foglalkoztatási adatokat javító cégeket (zombi vállalatok). ${ }^{32} \mathrm{~A}$ szolidaritás és a szociális inkluzivitás elve mindenek felett áll(t). ${ }^{33}$

\section{0 társadalom - digitális transzformáció az inkluzív fejlódés szolgálatában}

Ami tehát szemünk előtt kibontakozni látszik Japánban, az egy erősen értékalapú gazdasági kormányzás, amely - ahogy azt látni fogjuk - a digitális forradalom, az új ipari konfiguráció (ipar 4.0) és a mesterséges intelligencia kereszttüzében is igyekszik fennmaradni, sőt az inkluzivitás értékéhez hajlítani az átalakulást.

Nyilvánvaló, hogy speciális demográfiai helyzete miatt Japánnak elemi érdeke füződhetne a digitális transzformáció felgyorsításához, hiszen a népesség negyede 65 évnél idősebb, ezzel pedig Dél-Korea után a japán társadalomban figyelhető meg

\footnotetext{
${ }^{29}$ Később ez ellen Abe Shinzo gazdaságpolitikája is igyekezett tenni, de az őt követő Szuga Josihideadminisztráció is a verseny fokozásától, a deregulációtól és a fiskális és monetáris stimulustól várta a gyors eredményeket, amelyek a fájdalmas reformintézkedésekhez biztosíthatják a társadalmi tőkét. A jelenlegi, Kisida Fumio vezette kormányzatban is meglelni a kontinuitást.

${ }^{30}$ Honjo [2015] is dokumentálta ezt, ráadásul az egyének akkor hajlamosabbak befektetni és belevágni egy új üzletbe, ha és amennyiben a szükséges vállalkozói hálózat a rendelkezésükre áll. Tegyük hozzá, hogy ez a fajta együttmüködés-preferencia és gondolkodásmód kulturálisan kódolt Japánban: az úgynevezett „wa” koncepció arra késztet, hogy törekedjenek a csoportos és kollegiális gondolkodásra, s inkább a közösségi teljesítményt díjazzák, mintsem az egyénit (Sakamoto és szerzötársai [2012]).

${ }^{31}$ Világbank, World Development Indicators: https://databank.worldbank.org/source/worlddevelopment-indicators.

${ }^{32}$ Zombi vállalatok azok, amelyek csak az adósságuk után fizetendő kamatot képesek a nyereségből megfizetni, annak mértékét lecsökkenteni és fejlesztésbe invesztálni már nem.

${ }^{33}$ Japánban egy 10 ezer före kiterjesztett kérdőíves felmérés arra jutott, hogy a foglalkoztatottak 30 százaléka lát kiemelt kockázatot a mesterséges intelligenciában, a robotikában és automatizálásban (Morikawa [2017a], [2017b]). Ahol kimagasló jelentőségü a foglalkozásspecifikus készség, valamint ahol a személyes kapcsolatok és érintkezés meghatározóan preferált (gyermekgondozás, egészségügy, oktatás), ott nem félnek annyira a munkahelyek elvesztésétől (esetükben kisebb volt a járvány nyomására bevezetett távmunka részaránya is, lásd Okubo [2020]). Alapvetően tehát az igaz Japánban, hogy a számítástechnika előretörésével párhuzamosan nőtt az állásvesztések kockázata (ma a munkahelyek 55 százaléka felváltható lenne robotikával, automatizálással, ráadásul a leváltás veszélye a nem fóállású foglalkoztatottak esetében még nagyobb, lásd David [2017]).
} 
a legmagasabb függőségi ráta (vagyis a 15 évnél fiatalabbak és 64 évnél idősebbek százalékos aránya a munkaképes korú lakossághoz mérten). Japán népessége 2050-re 100 millió alá fog csökkenni, erős tehát a nyomás a munkamegtakarító mesterséges intelligencia és a digitalizáció irányába. ${ }^{34}$

Ugyanakkor olyan kulturális közegröl van szó, amelynek kísérőjelensége az egészségtudatosabb életvitel, ezért is lett gazdaságpolitikai preferencia a hosszú és aktív öregkor. Ezenkívül az elmúlt 30 évben a japán gazdasági kormányzás mindig szem előtt tartotta az úgynevezett támogató technológiák (assistive technologies) népszerüsítésének kérdését azért, hogy a fogyatékossággal élő emberek digitális szolgáltatásokhoz is hozzáférjenek, és ezzel is emelkedjen az inkluzivitás. ${ }^{35} \mathrm{~A}$ robotika alkalmazása is várat magára olyan területeken, ahol a személyes kapcsolatok fontosabbak (a 2015-ös új robotstratégia is beszámol arról, hogy a jelentős felhajtás ellenére azok a robotok, amelyek valóban képesek ellátni az ápolói és egyéb szolgáltató szektorokban szükséges feladatok sokaságát, még mindig a kutatás-fejlesztési szakaszban vannak - New Robot Strategy [2015]).

A 2008-as válságot követően is (az ipar 4.0 korában) a munkahelyvédelem élvezett elsőbbséget. A vállalatok elsősorban a munkaidőn csökkentettek, és nem terveztek elbocsátásokat (a munkaidő Japánban átlagosan 15 százalékkal esett vissza a 2008. évről a 2009. évre - Miyagawa-Ishikawa [2021]; viszont a nemzetközi standardokhoz képest is relatíve alacsony munkanélküliségi ráta nem változott). Itt nemcsak a szolidaritás kultúrája mutatkozik meg, hanem az a gazdasági-társadalmi nyomás is - a sokáig kimagaslóan elkeserítőnek számító öngyilkossági ráta feszélyező ereje -, amely a gazdaságpolitikát is arra ösztökélte, hogy az egzisztenciális bizonytalansághoz vezető elbocsátások kapcsán támogassák a cégeket a munkaerő megörzésében, terjesszék ki a lelkisegély-szolgálatot, stb. ${ }^{36}$

A nagy volumenü ipar 4.0 beruházások több okból késlekednek. Egyfelől az igaz, hogy a 2008-as válságot követően a Japánba beáramló extramennyiségü tőke elsősorban menedéket keresett, ami a jen felértékelődéséböl következett, s leszorította az exportdinamikát, azaz egyre kevesebb profitot eredményezett a japán cégeknél (Thorbecke [2019]). Ebböl fakadóan nincs elegendö pénzügyi forrás, ami a jelentős kezdeti beruházással (front-load investment) járó ipar 4.0 gyorsabb kiépítését célozná. Másrészt az is igaz, hogy Japánban jellemzően úgy fejlesztenek, hogy a robotika (mesterséges intelligenciára épülve) és automatizálás alkalmazása ugyan a lehető

\footnotetext{
${ }^{34}$ A magas függőségi rátából következik, hogy magas a robotika iránti igény. Japán e tekintetben is kiemelkedő, hiszen a világátlagnál jóval nagyobb mértékben fektet a mesterséges intelligenciába és a robotikába. A 10 ezer munkásra jutó robotok száma 360 körüli, ezzel a dél-koreai érték közelében van, s nagyjában-egészében közel háromszor annyit invesztálnak robotikába, mint az Egyesült Államok vagy Finnország (IFR [2021]).

${ }^{35} \mathrm{Az}$ ILO definíciója szerint támogató technológiának (assistive technology, AT) minősül minden információs és kommunikációs technológia, termék, eszköz, berendezés és kapcsolódó szolgáltatás, amelyet a sajátos igényű vagy fogyatékossággal élő személyek funkcionális képességeinek fenntartására, növelésére vagy fejlesztésére használnak. Japánban az idősödő társadalom miatt a támogató technológia kifejezetten fejlett (Crume [2018]).

${ }^{36} \mathrm{Ez}$ a politikai, gazdasági és társadalmi konstelláció gátolja a beruházásokat (Miyagawa-Ishikawa [2021]).
} 
legszélesebb körben valósuljon meg, de elsősorban úgy, hogy az ember és a gép együttmüködése maradjon a fö prioritás, nem pedig a gép-gép együttmüködés fejlesztése és mélyebb penetrációja.

A gépi tanulásnak és a mesterséges intelligencia kutatásának és alkalmazhatóságának állam oldaláról jövő kitüntetett tanulmányozása is a 2010-es években jött újra lendületbe. ${ }^{37} \mathrm{Az}$ iparfejlesztéssel kapcsolatos legutóbbi japán stratégia és vízió ${ }^{38}$ is tartalmazza azt a kitételt, hogy az ember-gép együttműködésnek központi szerepet kell szánni. Mindemellett a nagyvállalati konglomerátumok rendszerének lebontásában is nagy szerepe lehet a kis- és közepes méretű vállalkozások mesterséges intelligenciába és egyéb ipar 4.0 tevékenységbe történő határozottabb bekapcsolódását elősegítő támogatási programnak, ami egy szuperszámítógép (AI Bridging Cloud Infrastructure) kapacitását ajánlja föl az említett célcsoport képviselőinek annak érdekében, hogy előrébb jussanak a mesterséges intelligencia használata terén. Ráadásul a koronavírus-járvány okozta kármentési kényszer szülte költségvetési és monetáris élénkítésnek és direkt állami (és helyi szintü) támogatásoknak (a legsúlyosabban érintett szektoroknak és iparágaknak) az egyik meghatározó vezérmotívuma a szabadkereskedelem elvének további életben tartása, a globális értékláncokba eddig beépült cégek támogatása és újak serkentése a bekapcsolódásra. Vagyis nyomokban sem fedezhetö fel az ipar 4.0 technológiái - konkrétan mesterséges intelligencia, robotika, 3D nyomtatás - révén elérhető autarkabb fejlesztési út erőltetése, azaz ragaszkodnak a nemzetközi munkamegosztásra, béralapú versenyképességre épülő nemzetközi kereskedelmi felfogás szentségéhez. Mindebből pedig kiviláglik, hogy Japán valójában egy szuperokos, ám továbbra is emberközpontú társadalom (5.0-ás társadalom) elérésére törekszik. ${ }^{39}$

A nagyjában-egészében 11-12 ezer évvel korábban fennálló 1.0-ás társadalom (ősközösségi vadászó-gyüjtögető közösségek) után a letelepedő és földművelő 2.0 -ás társadalom köszöntött be, hogy aztán később az ipari forradalom létrehozza a sajátos 3.0-ás társadalmat, amelyet az 1970-es évektől datálható információs forradalom szövetébe ágyazódó 4.0-ás társadalom követett, s most jöhet a - gépi tanulás, mesterséges intelligencia, big data, ipar 4.0 technológiák (Kovács [2017a], [2017b]) által létrehozandó - kiberfizikai rendszerek világában újra emberi arányokkal felvértezett 5.0-ás társadalom. Utóbbi tehát egy emberközpontú társadalom, amely az internet, a mesterséges intelligencia és big data segítségével megvalósítja a rendszerek rendszerét (Rojas és szerzőtársai [2021]), vagyis a kiber- és fizikai terek összefüggő rendszerekbe történő integrálásával egyensúlyba hivatott hozni a gazdasági fejlődést a lokális és globális társadalmi problémák megoldásával (például az üvegházhatású emisszió

\footnotetext{
${ }^{37} 2015$ után jött létre Japán legnagyobb mesterséges intelligenciával kapcsolatos kutatás-fejlesztési központja is.

${ }^{38}$ Connected Industries Tokyo Initiative, 2017 (https://www.meti.go.jp/english/press/2017/ 1002_004.html).

${ }^{39}$ A koronavírus-járvány természetesen a magasabb fokú digitalizáltság felé tereli a gazdaságot a járványügyi intézkedések (például távolságtartás előírása) következtében. Minél előbb igyekeztek megteremteni a távmunka lehetőségét az állami szektorban (de a kis- és középvállalatokban is), távoktatásra rendezkedtek be, és minél több közszolgáltatást igyekeznek digitalizálni.
} 
csökkentése). ${ }^{40}$ Míg a 4.0-ás társadalom az információ bőségével tette keserédessé életünket - rendkívül nehéz a releváns információk kiszelektálása, tudássá alakítása és hatékony felhasználása -, addig az 5.0-ás társadalom az egyre fejlettebbé váló gépi tanulás és mesterséges intelligencia jóvoltából képes levenni ezt a terhet a vállunkról, így az egyes ember személyes kibontakozási lehetőségei könnyebben megalapozhatók, a társadalom széles rétege számára lesz realitás az aktív és élvezetes életvitel, a valódi fejlődés (1. táblázat).

\section{1. táblázat}

A 4.0-ás és az 5.0-ás társadalom összevetése

\begin{tabular}{lll}
\hline A 4.0-ás társadalom problémája & $\begin{array}{l}\text { Áthidaló } \\
\text { technológia }\end{array}$ & Az 5.0-ás társadalom megoldása \\
\hline
\end{tabular}

Az információ túlcsordulásával a kívánt információ megtalálása és elemzése egyre nehezebbé és megterhelőbbé vált (töméntelen mennyiségű adat vált emberek által hozzáférhetővé, például felhőalapú szolgáltatások révén, de azok elemzése és kiértékelése emberi készségeken és képességeken múlt).

Az emberek jellemzően nagy mennyiségű munkát végeznek, képességeiknek komoly korlátjai vannak, a fogyatékkal élők és hátrányos helyzetűek munkavégzési lehetőségei is erősen korlátozottak.

Jellemző az információáramlás zavara, A dolgok a „silógondolkodás”, és erőteljesen limitált a tudás és az információ megosztása, így az ágazatok között nehéz hozzáadott értéket teremteni.

Az elöregedő társadalom és a regionális elnéptelenedés nagy szakadékot jelez az információs társadalomban boldogulni képes, ám egyre kisebb társadalmi réteg és az egyre bővülő leszakadók között.

Robotika, internete

Mesterséges
intelligencia,
szenzoralapú
hálózatok.
automatizáció. és automatizálás bővíti

lehetőségeinket, nagyobb tér nyílik az inkluzív fejlődésre (az ember-gép kapcsolat segít áthidalni sokféle fogyatékosságot, stb.). ${ }^{*}$

A szenzoralapú hálózatok elburjánzásával még több és még nagyobb részletezettségü adat keletkezik. A mesterséges intelligencia megszabadítja az embert az információáradat elemzésének terhétől (például precízebb orvosi diagnosztika jöhet létre a mesterséges intelligencia közremüködésével, stb.). ${ }^{*}$ Az emberközpontú robotika A dolgok internete összekapcsol (Internet of mindenféle tudás és információ Things). megosztásra kerül, így teljesen új érték születhet.

\section{Okoseszközök, Bizonyos újfajta technológiák és} szenzorok, 3D rájuk épülő szolgáltatások (például nyomtató. drónposta) révén mérsékelhető a szakadék (az önvezető taxik és buszok segítenek a soförhiány megszüntetésében, jobban bekapcsolva ezzel a vidéki területeket a gazdaságba).

\footnotetext{
${ }^{40}$ Tulajdonképpen a globális és lokális társadalmi problémák kezelhetőségében az ipar 4.0-nak kiemelt szerep tulajdonítható például az energiahatékonyság növelése, a szén-dioxid-kibocsátás mérséklése terén. Továbbá az ipar 4.0 és a környezeti fenntarthatóság kapcsolatáról lásd még Romero és szerzőtársai [2021]. Az 5.0-ás társadalom elképzelését a japán 5. tudomány és technológiai alapterv (5th Science and Technology Basic Plan) tartalmazta, amelyről kormánydöntés 2016 januárjában született.
} 
Az 1. táblázat folytatása

A 4.0-ás társadalom problémája $\begin{aligned} & \text { Áthidaló } \\ & \text { technológia }\end{aligned} \quad$ Az 5.0-ás társadalom megoldása

Az információs forradalom nem eredményezett tartós és látványos termelékenységi boomot, sőt az ökológiai lábnyom sem tudott mérséklődni, miközben az államra rakódó költségek csak növekedtek.

\begin{tabular}{|c|c|}
\hline $\begin{array}{l}\text { Ipar } 4.0 \text { és } \\
\text { mesterséges } \\
\text { intelligencia. }\end{array}$ & $\begin{array}{l}\text { Az iparban létrejövő okosgyárak, } \\
\text { valamint az élet megannyi } \\
\text { területéről érkező valós idejű big } \\
\text { data mesterségesintelligencia- } \\
\text { alapú felhasználása hatékonyabb, } \\
\text { a tényleges szükségletekhez igazított } \\
\text { termelést és szolgáltatásokat } \\
\text { ígér, kevesebb felesleggel, } \\
\text { energiafelhasználással és hulladékkal. } \\
\text { A szenzorok, a mesterséges } \\
\text { intelligencia és a veszélyesebb } \\
\text { munkákra szakosodó robotok } \\
\text { segítségével az állami infrastruktúra } \\
\text { költséghatékonyabb felügyelete és } \\
\text { karbantartása végezhető el. }\end{array}$ \\
\hline
\end{tabular}

Ipar 4.0 és

Az iparban létrejövő okosgyárak, valamint az élet megannyi data mesterségesintelligenciaalapú felhasználása hatékonyabb, a tényleges szükségletekhez igazított termelést és szolgáltatásokat ígér, kevesebb felesleggel, A szenzorok, a mesterséges intelligencia és a veszélyesebb munkákra szakosodó robotok segítségével az állami infrastruktú karbantartása végezhető el.

* Robottudósok új tudományos felfedezésekre képesek (például hipotéziseket fogalmaznak meg élesztőgombákról, kísérleti úton pedig igazolják vagy elvetik azokat; a Rose nevű robotplatform pedig segít komplex idegsebészeti eljárások minimális mértékű invazívvá tételében).

** Például a BioMind mesterségesintelligencia-rendszer sikeresebbnek bizonyult a tumordiagnosztika terén a világ orvoselit csapatával szemben (Parizel [2018]).

Forrás: saját összeállítás.

Az 5.0-ás társadalom elérése szempontjából Japán relatíve jó pozícióban van. 1. Az univerzális egészségügyi (digitális szolgáltatásokkal és adatkezeléssel övezett) rendszer, valamint a viszonylag magas fokon digitalizált termelői szektor gazdag adathalmazt generál hónapról hónapra (big data), ami kiváló inputja lehet a mesterségesintelligencia-alapú komplex elemzéseknek. ${ }^{41}$ Japán tulajdonképpen a világ második olyan társadalma, ahol a mesterséges intelligencia alkalmazása és a bigdata-alkalmazások száma a legkiemelkedőbb (WIPO [2019]). Természetesen a kiberbiztonság terén a szabályozói oldalon is elörelépésre van szükség ahhoz, hogy a gazdasági szereplők kockázatkerülő magatartása tompíthatóvá váljon (Felkner és szerzőtársai [2021]). 2. Robotika és automatizálás terén Japán szintén élen járó, ahol a robotizáció gyakorlatilag az ipari gyártás (monozukuri) központi hajtóereje (Kovacic [2018]). Végső soron az államháztartás hosszú távú kiegyensúlyozottságára is jótékonyan hat az 5.0-ás társadalom kiépítése, hiszen az említett technológiák révén viszszafoghatóvá válnak az államadósság jelentős részéért felelős egészségügyi és társadalombiztosítási kiadások. ${ }^{42}$

\footnotetext{
${ }^{41}$ Big Data a turizmus és vendéglátás (Bakdur és szerzőtársai [2018]), az egészségügy (Nohara és szerzőtársai [2019], Wang-Alexander [2019], Ishii és szerzötársai [2020], Tsuji [2020]), a termelöi szektor (Motohashi [2017]) és az állami szektor területén.

${ }^{42}$ Az egészségügyi adatok összekapcsolása és megosztása hatékonyabb orvosi diagnózishoz és kezeléshez vezet. A távoli orvosi ellátás csökkenti az idős emberek kórházlátogatásait.
} 


\section{Következtetések}

Nobel-díjának átvételekor Friedrich August von Hayek felhívta a figyelmet arra, hogy a társadalmi-gazdasági rendszer komplexitásából adódóan a gazdasági kormányzás őrizkedjen a folytonos optimalizálástól - mert azzal csak árt, torzításokhoz, bizalmatlanságokhoz vezet -, és inkább arra törekedjen, hogy segítsen elkerülni a nagyon súlyos károkkal járó kimeneteket (Hayek [1974]). Írásunkban amellett érveltünk, hogy a digitális transzformáció némiképp árnyalhatja ezt az intést, ugyanis az automatizálhatóság magas foka, a mesterséges intelligencia és a robotika szédítő fejlődése alapvetően károsan érinti a gazdaságok foglalkoztatási kapacitását, ami az értelmes és értékes munkán keresztül a társadalmi mobilitás müködésének egyik fontos tényezője. Ahogy rámutattunk, az egyenlötlenségek növekedése - de így az elszegényedés dinamikus folyamata, a középosztály zsugorodása is - a fejlett világ új normálállapotává vált, ezért a nacionalizmus és populizmus elöretörése logikus fejlemény volt. Ezután arra tértünk ki, hogy a körülmények uralják az embert, s nem pedig fordítva. Vagyis: noha a nemzetközi térben mintha egyre sziklaszilárdabbá válna a fenntartható fejlődési célok elérése, az inkluzív fejlödés meglehetősen exkluzív jellegü, hovatovább a politikai stabilitás sine qua nonjává válik. Felsejlik tehát a horizonton egy, az inkluzivitásért síkra szálló (talán ebből a szempontból intervencionistább) állam, amely afféle szociális digitális transzformáció útjára lép. Bár az idézett Hayek szerint a szociális jelző csak afféle fosztóképző - azaz például a szociális piac nem piac -, a szociális dimenzió nyomatékosabb érvényre juttatása iránt, úgy tűnik, nagyobb most az igény a digitális gazdaság kiépülése során, mint valaha. Erre hoztuk illusztrációként Japánt, ahol a motivált hitekkel (motivated beliefs and reasoning) kapcsolatos irodalomra (lásd például Bénabou-Tirole [2016]) találhattunk utalást, nevezetesen, hogy a japán gazdasági kormányzás értéket társít az inkluzív fejlődéshez, ami tulajdonképpen a legkülönfélébb társadalmi szorongás csillapításának eszközeként erösíti a japán társadalmi identitást, a közösségek megörzésének és bennük a harmónia megteremtésének nagyrabecsülését.

Összességében tehát a digitális transzformáció és az ipar 4.0 kapcsán pesszimizmusunknak adtunk hangot rövid távon, ám hosszú távon akár optimisták is lehetünk. Ehhez pedig lépésekre van szükség. A következőkben a tanulmányunkban elöadottakra és a japán út tapasztalataira építve fogalmazzuk meg azokat az alapelveket, amelyek szerint érdemes lehet elindulnia az európai gazdasági kormányzásnak a már említett két gazdaságpolitikai cél összeegyeztethetősége érdekében, vagyis a digitális átalakulás előrelendítése és az inkluzív fejlődés bebiztosítása felé vezető úton.

1. A fokozatosság elvének érvényre juttatását érdemes szem előtt tartani, amikor az állam a digitális gazdaság kiépülését és kiteljesedését támogatni igyekszik. A gazdaságtörténet ugyanis egy dologra mindenképp megtanít: a fejlődés ára nagy társadalmi felfordulás lehet, ha nincsenek ellensúlyozó mechanizmusok. Klasszikus munkák e tekintetben Toynbee [1962], illetve Polányi [2004].

2. A közvetett munkahelyteremtés preferálása, mert a közvetlen állami munkahelyteremtés nem szolgálná a fenntartható transzformációt.

3. Folyamatos felülvizsgálatra és komplex kölcsönhatások figyelembevételére van szükség, mert nem minden inkluzív növekedés fenntartható (például nagy 
foglalkoztatási ráta mellett esetleg a fenntartható fejlődési célok sorra sérülnek; a lélegeztetőgépen tartott cégek esetleg már régen kiszelektálódtak volna; stb.).

4. A ,jó munkahely" koncepciója egy mozgó célpont, további kutatások szükségesek definiálásához; minden bizonnyal kontextusfüggő fogalom, viszont elengedhetetlen, ha a gazdasági kormányzás az inkluzivitás erősítésén kíván dolgozni.

5. Értékalapú inkluzív gazdasági kormányzás: olyan mechanizmusokra van szükség, amelyekkel nagy valószínüséggel elö lehet mozdítani $a$ ) a már létező és versengő vállalatoknál a termelékenyebb foglalkoztatási kapacitás növelését, $b$ ) a termelékenyebb foglalkoztatást ígérő cégek számának gyarapodását, $c$ ) a munkaerőnek a digitális gazdaság fejlődése szempontjából előrevivő fejlesztését (például oktatási beruházással kell segíteni az alacsonyabb jövedelmü családokból jövő tehetségek sikeresebb integrációját; átképző programokra van szükség az automatizálással való együttes létezés/munkavégzés megkönnyítéséhez, továbbá társadalombiztosítási megoldásokra az állásaikat elvesztők számára), $d$ ) mikroszinten az innováció munkaerőbarát irányba terelését (például támogatási megoldások a munkaerőbázis növelésére), e) a progresszív adórendszerek reaktiválását az egyenlőtlenségek mérsékléséhez és a nagyfokú koncentrációk csillapításához. ${ }^{43}$

Írásunkkal nem az állami beavatkozás bővülése mellett tesszük le voksunkat, sőt a már többször idézett Hayekhez hasonlóan mi is veszélyt látunk az intenzív állami intervencionizmusban. ${ }^{44}$ Amellett érveltünk, hogy a gazdasági-társadalmi innovációs ökoszisztéma minőségi változása során bizonyos missziókat fel kell vállalnia az államnak önmaga fenntarthatósága, a folyamatok társadalmi elfogadhatósága és gazdasági/ környezeti szempontok megvalósíthatósága érdekében. Japán esete azt példázza, hogy a gazdasági kormányzás számára lehetőség van arra, hogy az ország hagyományaihoz és értékeihez hajlítsák a digitális transzformációt. Az innovációs irodalom terminológiájával ezt úgy is megfogalmazhatjuk, hogy a gazdasági kormányzás nem kell, hogy érintetlenül hagyja a technológiai innovációk primátusát a digitális transzformáció és az ipar 4.0 átalakulás során, beavatkozásai és koordinációs tevékenysége során törekedhet arra, hogy a folyamatok végeredményben az emberi képességek további kultiválását szolgáló szociális innovációkká váljanak.

A társadalmi-gazdasági innovációs ökoszisztéma mennyiségi növekedése is korlátos, muszáj az inkluzív és fenntartható növekedésre, illetve fejlődésre jobban összpontosítani. Ehhez a komplexitást jobban kezelö közgazdaság-tudományi megközelítésre is szükség van (Kovács [2022]), ami hathatósabban támogatná a gazdasági kormányzást abban, hogy a fenntartható inkluzív fejlödést helyezze a digitális forradalom középpontjába.

\footnotetext{
${ }^{43}$ Utóbbi a középosztály megerősítése miatt fontos, ami a kapitalizmus fönnmaradásának egyik peremfeltétele (Milanovic [2021] 297. o.).

${ }^{44}$ Hayek Út a szolgasághoz című műve (Hayek [1944/1991]) pontosan arról szólt, hogy a spontán fejlödést a szabadon hagyott piac biztosítja, $s$ annak bárminemü korlátozása a szocializmuson keresztül totalitárius rezsimek felé vezet. Hayek később önmérsékletet tanúsított, és az 1976-os kiadásban már arról szólt, hogy a diktatúra nem szükségszerü következménye az állami intervencionizmusnak (Hayek [1974]).
} 


\section{Hivatkozások}

Acemoglu, D.-Restrepo, P. [2019]: The Wrong kind of AI? Artificial Intelligence and the Future of Labour Demand. Cambridge Journal of Regions, Economy and Society, Vol. 13. No. 1. 25-35. o. https://doi.org/10.1093/cjres/rsz022.

Alesina, A.-Perotti, R. [1996]: Income Distribution, Political Instability, and Investment. European Economic Review, Vol. 40. No. 6. 1203-1228. o. https://doi.org/10.1016/00142921(95)00030-5.

Atkinson, A. B. [2017]: Egyenlőtlenség. Kossuth Kiadó, Budapest.

Bakdur, A.-Masui, F.-Ptaszynski, M. [2018]: Big Data Analytics - Towards the Enrichment of Content Tourism for Revitalization of Japanese Rural Area. MATEC Web of Conferences 169, 01008. https://doi.org/10.1051/matecconf/201816901008.

Baudrillard, J. [1983]: Simulations. Semiotext[e], Los Angeles, California.

Bénabou, R.-Tirole, J. [2016]: Mindful Economics: The Production, Consumption, and Value of Beliefs. Journal of Economic Perspectives, Vol. 30. No. 3. 141-164. o. https://doi. org/10.1257/jep.30.3.141.

Bergeaud, A.-Cette, G.-Lecat, R. [2016]: Productivity Trends in Advanced Countries between 1890 and 2012. Review of Income and Wealth, Vol. 62. No. 3. 420-444. o. https:// doi.org/10.1111/roiw.12185.

Birdsall, N. [2016]: Middle-Class Heroes: The Best Guarantee of Good Governance. Foreign Affairs, Vol. 95. No. 2. 25-32. o.

Chun, H.-Fukao, K.-Kwon, H. U.-Park, J. [2021]: Why Do Real Wages Stagnate in Japan and Korea? RIETI Discussion Paper Series, No. 21-E-010. https://www.rieti.go.jp/jp/ publications/dp/21e010.pdf.

Crume, Y. [2018]: Assistive Device Revolution for the Independence of Older Adults in Japan. Care Robots and Other Technology Innovations. International Longevity Center, Japan, https://www.ilcjapan.org/studyE/doc/2018_1.pdf.

David, B. [2017]: Computer Technology and Probable Job Destructions in Japan: An Evaluation. Journal of the Japanese and International Economies, Vol. 43. No. 1. 77-87. o. https:// doi.org/10.1016/j.jjie.2017.01.001.

Easterly, W. [2001]: The Middle Class Consensus and Economic Development. Journal of Economic Growth, Vol. 6. No. 4. 317-335. o. https://doi.org/10.1023/a:1012786330095.

Eurostat [2022a]: Income quintile share ratio S80/S20 for disposable income by sex and age group. EU-SILC survey. Eurostat, https://ec.europa.eu/eurostat/databrowser/view/ILC_ DI11_custom_1915785/default/line?lang=en.

Eurostat [2022b]: COVID-19: Statistics serving Europe. Eurostat, https://ec.europa.eu/ eurostat/web/covid-19/overview.

Felkner, A.-Kadobayashi, Y.-Janiszewski, M.-Fantin, S.-Ruiz, J. F.-Kozakiewicz, A.Blanc, G. [2021]: Cybersecurity Research Analysis Report for Europe and Japan. Cybersecurity and Privacy Dialogue between Europe and Japan. Springer, Studies in Big Data, No. 75. https://doi.org/10.1007/978-3-030-62312-8.

Flew, T. [2006]: The New Middle Class Meets the Creative Class: The Masters of Business Administration (MBA) and creative innovation in 21st-century China. International Journal of Cultural Studies, Vol. 9. No. 3. 419-429. o. https://doi.org/10.1177/1367877906066887.

FuKUDA, K. [2020]: Science, Technology and Innovation Ecosystem Transformation toward Society 5.0. International Journal of Production Economics, Vol. 220. No. 107460. https:// doi.org/10.1016/j.ijpe.2019.07.033. 
Guiso, L.-Herrera, H.-Morelli, M.-Sonno, T. [2018]: Economic Insecurity and the Demand of Populism in Europe. Bankpedia Review, Vol. 7. No. 1-2. 61. o. https:// ieawc2021.org/wp-content/uploads/2021/06/44a4c41c3791-Herrera_Helios_Populism_ SupplySide.pdf.

Hawkins, D. I. [1993]: New Business Entrepreneurship in the Japanese Economy. Journal of Business Venturing, Vol. 8. No. 2. 137-150. o. https://doi.org/10.1016/0883-9026(93)90016-x. HAYEK, F. A. vON [1944/1991]: Út a szolgasághoz. Közgazdasági és Jogi Könyvkiadó, Budapest. Hayek, F. A. von [1974]: The Pretence of Knowledge. Lecture to the memory of Alfred Nobel. The Nobel Foundation, december 11. https://www.nobelprize.org/prizes/economicsciences/1974/hayek/lecture/.

Hayek, F. A. von [1976]: The Road to Serfdom. Routledge \& Kegan Paul PLC.

Honjo, Y. [2015]: Why Are Entrepreneurship Levels So Low in Japan? Japan and the World Economy, Vol. 36. 88-101. o. https://doi.org/10.1016/j.japwor.2015.08.002.

IFR [2021]: Robot Race: The World's Top 10 automated countries. IFR Robotics. https://ifr. org/ifr-press-releases/news/robot-race-the-worlds-top-10-automated-countries.

Ikeuchi, K.-Fukao, K.-Perugini, C. [2021]: Establishment Size, Workforce Composition and the College Wage Gap in Japan. RIETI Discussion Paper, No. 21-E-022. https://www. rieti.go.jp/jp/publications/dp/21e022.pdf.

Ishit, E.-Ebner, D. K.-Kimura, S.-Agha-Mir-Salim, L.-Uchimido, R.-Celi, L. A. [2020]: The Advent of Medical Artificial Intelligence: Lessons from the Japanese Approach. Journal of Intensive Care, Vol. 8. No. 35. https://doi.org/10.1186/s40560-020-00452-5.

Kang, M.-K. [2017]: The Confidence Trap: Japan's Past Bubble and China's Recent Bubble. New Political Economy, Vol. 23. No. 1. 1-26. o. https://doi.org/10.1080/13563467.2017. 1321626.

Kettenhofen, L. [2021]: Startups in Japan - Statistics \& Facts, Finance \& Insurance. Statista, január 25. https://www.statista.com/topics/4744/startups-in-japan/.

KirkegaArd, J. F. [2019]: Yes, We Are Probably All Japanese Now. Monetary Dialogue. September 19. In-depth analysis, European Parliament, Luxembourg, https://www.europarl.europa.eu/cmsdata/207623/13. százalék20PIIE_FINAL-original.pdf.

KomLOs, J. [2016]: Growth of income and welfare in the U.S. 1979-2011. NBER Working Paper, No. 22211. https://doi.org/10.3386/w22211.

Kovacic, M. [2018]: The Making of National Robot History in Japan: Monozukuri, Enculturation and Cultural Lineage of Robots. Critical Asian Studies, Vol. 50. No. 4. 572-590. o. https://doi.org/10.1080/14672715.2018.1512003.

Kovács Olivér [2017a]: Az ipar 4.0 komplexitása - I. rész. Közgazdasági Szemle, 64. évf. 7-8. sz. 823-851. o. https://doi.org/10.18414/KSZ.2017.7-8.823.

Kovács Olivér [2017b]: Az ipar 4.0 komplexitása - II. rész. Közgazdasági Szemle, 64. évf. 9. sz. 970-987. o. https://doi.org/10.18414/KSZ.2017.9.970.

KovÁcs OLIVÉr [2022] (megjelenés alatt): Complexity Economics: Economic Governance. Science and Policy. Routledge, London-New York.

Madland, D. [2015]: Hollowed Out: Why the Economy Doesn't Work Without a Strong Middle Class. University of California Press.

Milanovic, B. [2021]: Egyedül a kapitalizmus. A világot uraló rendszer jövője. Osiris Kiadó, Budapest.

Miyagawa, T.-Ishikawa, T. [2021]: Declining Capital Formation in Japan and the Role of Intangibles: Empirical Studies using Industry-level Data. Research Institute of Economy, Trade and Industry, Discussion Paper, No. 21-J-020. 
Morikawa, M. [2017a]: Firms' Expectations about the Impact of AI and Robotics: Evidence from a Survey. Economic Inquiry, Vol. 55. No. 2. 1054-1063. o. https://doi.org/10.1111/ ecin.12412.

Morikawa, M. [2017b]: Who Are Afraid of Losing Their Jobs to Artificial Intelligence and Robots? Evidence from a Survey. RIETI Discussion Paper, No. 17-E-069. https://www.rieti. go.jp/jp/publications/dp/17e069.pdf.

Мотонаshi, K. [2017]: Survey of Big Data Use and Innovation in Japanese Manufacturing Firms. RIETI Policy Discussion Paper Series, No. 17-P-027. https://www.rieti.go.jp/jp/ publications/pdp/17p027.pdf.

New Roвot Strategy [2015]: New Robot Strategy. Japan's Robot Strategy. Vision, Strategy, Action Plan. The Headquarters for Japan's Economic Revitalization. https://www.meti. go.jp/english/press/2015/pdf/0123_01b.pdf.

Nohara, S.-Shibata, T.-Ishi, K.-Obara, H.-Miyamoto, T.-Kakuma, T.-Fukumoto, Y. [2019]: Cancer Therapeutics-related Heart Failure from a Cohort Study Using Big Data of Electronic Health Record in Japan. European Heart Journal, Vol. 40. No. 1. https://doi. org/10.1093/eurheartj/ehz745.0196.

OECD [2011]: Divided We Stand: Why Inequality Keeps Rising. OECD, Párizs.

OECD [2017]: OECD Science, Technology and Industry Scoreboard 2017: The digital transformation. OECD Publishing, Párizs, http://dx.doi.org/10.1787/9789264268821-en.

OECD [2018]: Decoupling of Wages from Productivity: What Implications for Public Policies? Chapter 2. OECD Economic Outlook, No. 2. https://www.oecd.org/economy/outlook/ Decoupling-of-wages-from-productivity-november-2018-OECD-economic-outlookchapter.pdf.

OECD [2019a]: Job Polarisation and the Middle Class: New Evidence on the Changing Relationship between Skill Levels and Household Income Levels from 18 OECD Countries. OECD Social, Employment and Migration Working Papers, No. 232. https:// doi.org/10.1787/4bf722db-en.

OECD [2019b]: Under Pressure: The Squeezed Middle Class. Overview and Main Findings. OECD, Párizs, https://www.oecd.org/els/soc/OECD-middle-class-2019-main-findings.pdf.

OECD [2020]: Financing SMEs and Entrepreneurs 2020: An OECD Scoreboard. OECD, Párizs, https://doi.org/10.1787/23065265.

OECD [2022]: Youth Not in Employment, Education or Training (NEET). OECD.Data, https:// data.oecd.org/youthinac/youth-not-in-employment-education-or-training-neet.htm.

Ogburn, W. F. [1964]: On Culture and Change. Selected Papers, University of Chicago Press, Chicago.

Окиво, T. [2020]: Spread of COVID-19 and telework: Evidence from Japan. Keio-IES Discussion Paper Series.

Parizel, P. M. [2018]: I've Seen the Future: A Competition between Physicians and AI. European Society of Radiology, https://www.myesr.org/article/1840.

Piketty, T. [2015]: A tőke a 21. században. Kossuth Kiadó, Budapest.

Polányi Károly [2004]: A nagy átalakulás. Korunk gazdasági és politikai gyökerei. Napvilág Kiadó, Budapest.

Prettner, K.-Bloom, D. [2020]: Automation and Its Macroeconomic Consequences. Theory, Evidence, and Social Impacts. Academic Press, Cambridge, MA.

Rовотs... [1982]: Robots - Japan's Fastest Growth Industry. The Production Engineer, Vol. 61. No. 4. https://doi.org/10.1049/tpe.1982.0047. 
Rodrik, D. [2019]: Building a Good Jobs Economy. Harvard University Working Paper. https://drodrik.scholar.harvard.edu/publications/building-good-jobs-economy.

Rojas, C. N.-Peñafiel, G. A. A.-Buitrago, D. F. L-Romero, C. A. T. [2021]: Society 5.0: A Japanese Concept for a Superintelligent Society. Sustainability, Vol. 13. No. 12. 6567. https://doi.org/10.3390/su13126567.

Romero, C. A. T.-Castro, D. F.-Ortiz, J. H.-Khalaf, O. I.-Vargas, M. A. [2021]: Synergy between Circular Economy and Industry 4.0: A Literature Review. Sustainability, Vol. 13. No. 8. 4331. https://doi.org/10.3390/su13084331.

Sakamoto, A.-Woo, H.-Takei, I.-Murase, Y. [2012]: Cultural Constraints on Rising Income Inequality: A U.S. - Japan Comparison. The Journal of Economic Inequality, Vol. 10. 565-581. o. https://doi.org/10.1007/s10888-011-9204-1.

Sen, A. [1993]: Capability and Well-Being. Megjelent: Nussbaum, M.-Sen, A. (szerk.): The Quality of Life. Clarendon, Oxford, 30-53. o. https://doi.org/10.1093/0198287976.003.0003.

SEN, A. [2021]: Az igazságosság eszméje. Osiris Kiadó, Budapest.

Sen, A.-Sengupta, S. [1983]: Malnutrition of Rural Children and the Sex Bias. Economic \& Political Weekly, Vol. 18. No. 19-20-21. 855-864. o.

Swan, P. L. [1970]: Market Structure and Technological Progress: The Influence of Monopoly on Product Innovation. The Quarterly Journal of Economics, Vol. 84. No. 4. 627-638. o. https://doi.org/10.2307/1880843.

Thorbecke, W. [2019]: Why Japan Lost its Comparative Advantage in Producing Electronic Parts and Components. RIETI Discussion Paper, No. 19-E-035.

Toynbee, A. J. [1962]: The Present-Day Experiment in Western Civilization. Oxford University Press, 74 o.

TsujI, Y. [2020]: Medical Big Data in Japan. Journal of Law \& Cyber Warfare, Vol. 8. No. 1. 153-168. o.

Wang, L.-Alexander, C. A. [2019]: Big Data Analytics in Healthcare Systems. International Journal of Mathematical, Engineering and Management Sciences, Vol. 4. No. 1. 17-26. o. https://doi.org/10.33889/IJMEMS.2019.4.1-002.

WIPO [2019]: Artificial Intelligence. WIPO Technology Trends. https:/www.wipo.int/edocs/ pubdocs/en/wipo_pub_1055.pdf. 